\title{
A Comparative Analysis of a Shared (Inter)National Story: How Brazilian and US Presses Covered Sean Goldman's Recovery
}

\author{
Tania Cantrell Rosas-Moreno ${ }^{1} \&$ Dustin Harp ${ }^{2}$ \\ ${ }^{1}$ Loyola University Maryland, USA \\ ${ }^{2}$ The University of Texas at Arlington, USA \\ Correspondence: Tania Cantrell Rosas-Moreno, Loyola University Maryland, Department of Communication, \\ 4501 North Charles Street, Baltimore, MD 21210, USA. Tel: 1-512-203-6400. E-mail: \\ tcrosasmoreno@loyola.edu
}

Received: March 5, 2013 Accepted: March 21, 2013 Available online: May 8, 2013

doi:10.11114/smc.v1i1.84

URL: http://dx.doi.org/10.11114/smc.v1i1.84

\begin{abstract}
Journalists do not tell audiences the truth but versions of stories they understand to be true based on what they have seen and know. This comparative analysis of $41 \mathrm{US}$ and Brazilian news reports investigates the first return of an international child abductee from the United States to Brazil and back: Sean Goldman. Framing theory along with the ideological level of the hierarchical model of news influences help clarify four salient latent news frames that arise when two somewhat similar nations with different press systems tell this (inter)national story: $A$ game of high stakes; The muted prize; US citizen superhero; and Remember the press, forget the subject. That the players involved in the story come from the right race and class evidences how and why this one incident became a shared news event that rose to the highest offices of each land. More comparative studies about (inter)national journalistic practices and institutions are called for.
\end{abstract}

Keywords: framing theory, hierarchical model of news influences, Goldman, race and class in news, journalistic ideologies, shared news event

\section{Introduction}

Journalists do not tell audiences the truth but versions of stories they understand to be true based on what they have seen and know. How journalists construct a story - a particular truth - is influenced by a hierarchy of levels (Shoemaker \&Reese, 1996), including newsroom routines, norms, values and, perhaps most powerfully, ideological perspectives such as those of race and class. This research compares news coverage of a resolved international kidnapping case in the US and Brazilian presses to determine how ideology becomes evident in the case coverage, considering two questions. How did US and Brazilian national and local presses frame this shared news event, and what might that framing indicate about journalistic practices and/or institutions?

International kidnapping is a troublesome issue, given that yearly 800,000 children are reported missing in the United States, with family members abducting approximately 200,000 (Finkelhor 2002/2003). Treaties like the Hague Abduction Convention, enforced between signatory nations beginning December 1983, provide "a mechanism for signatory countries to solve international child abduction cases" (Semple, 2009), yet few children are recovered.

Sean Goldman is the first and, to date, only abducted child to be returned to the United States from Brazil, host to at least another 50 abducted children. Sean rejoined his father, US citizen David Goldman, Christmas Eve 2009, five years after his Brazilian mother, Bruna Bianchi, took him on "vacation" to Brazil. The international custody battle was long and uniquely complex; while home in Brazil, Bruna divorced her US husband in Brazilian courts without David's consent, married Brazilian divorce attorney João Paulo Lins e Silva - a fifth-generation lawyer working in a family-owned business that practices international family law, and then died after complications from childbirth. David fought under The Hague Treaty "against people with substantial influence at high levels in the Brazilian judiciary system, government and media" to regain custody and repatriate him (Bring Sean Home Foundation, 2012a). 
In September 2008, while in Brazil seeking his son for about the $11^{\text {th }}$ time since his abduction, David wrote a letter to his local elected officials and the New York/New Jersey media. Once picked up by NBC's Today Show, US Representative Chris Smith of New Jersey's $4^{\text {th }}$ Congressional District stepped in. US Representative Rush Holt of New Jersey's $12^{\text {th }}$ Congressional District also aided, speaking with Secretary of State Hillary Clinton, about efforts to reunite Sean with his father (Bring Sean Home Foundation, 2012b). Ultimately, President Barack Obama became involved, speaking with Brazilian President Luiz Inácio Lula da Silva on their first meeting about Sean's return (Casares, 2009). Media coverage in both nations escalated and, finally, father and son legally reunited.

Sean, who had been told his father had abandoned him and only saw his father during the five-year separation toward its end, recently went public about his experience in the ordeal. More than two years after his repatriation, Sean told his story Friday, April 27, 2012, via the Today Show and later that day with NBC's Meredith Vieira on "Dateline." He hopes now to be an example of how and why abducted children need to get back home (Stomp, 2012). To combat other international child abductions, the "Sean and David Goldman International Child Abduction, Prevention and Return Act," is currently working its way through Congress (Stump, 2012). The legislation aims to help return American children home who are victims of international abduction.

Scholars have investigated the sensational Thanksgiving 1999 abduction of Cuban child Elian Gonzalez, which also received significant amounts of media coverage (see, for example, Contreras, 2000). Yet, those studies, which include important analysis of Latinidad (see, for example, Guzmán, 2005; Méndez-Méndez \& Alverio, 2001), fail to compare if or how Elian's story was told in the Cuban press. This comparative narrative analysis explores the framing of 41 free-press-ranked US and partly-free-press-ranked Brazilian national and local reports to show how each nation's media spotlighted the ideological aspects of the case, primarily the fathers' race and class.

\section{Influences, Framing and Frames}

Communication scholars point to a number of factors influencing news content. Shoemaker and Reese (1996) organized those influences into a hierarchical model illustrating five concentric circles. In the inner circle, the authors note, an individual reporter's personal background and experiences have a degree of influence on the structuring of a story. The authors offered media routines in the form of a larger circle encompassing the individual and illustrating greater influence on news stories. Next and moving outward in the hierarchy of influences are organizational, extra media, and finally, the ideological levels (Shoemaker \& Reese, 1996). This research focuses on this final level, the ideological.

Through a framing analysis of the same news event in newspapers from two countries, this research considers how the ideological level of influence - particularly race and class - impact the telling of a story. Framing is "... as central a concept there is to the study of communication" (D'Angelo, 2010, p. 365). It considers (un)intentional manifest, or informational, along with latent, or interpretive, content to help decipher message meaning. Manifest and latent frames result from cultural negotiation and (news) production.

"Frames are organizing principles that are socially shared and persistent over time, that work symbolically to meaningfully structure the social world" (Reese, 2003, p. 11, italics in original). Frames are tools social actors such as journalists use to structure reality and are often so taken-for-granted that their impact is by stealth (Lewis \& Reese, 2009; Gamson \& Modigliani, 1989; Van Gorp, 2007). Because frames are culturally (and ideologically) embedded, they “... form universally understood codes that implicitly influence the receiver's message interpretation, which lends meaning, coherence, and ready explanations for complex issues" (Van Gorp, 2010, pp. 87-88). They are dynamic, active, negotiated elements that uniquely link media producers, content and audiences across time and space (Cantrell \& Bachmann, 2008).

Framing fundamentally engages selection and salience. To frame is to "select some aspects of a perceived reality and make them more salient in a communicating text, in such a way as to promote a particular problem definition, causal interpretation, moral evaluation, and/or treatment recommendation" for the event described (Entman, 1993, p. 52). This research deepens our knowledge of news work, journalistic national allegiance, and the framing of race and social class in the US and Brazil by illustrating how journalists from different countries frame the same story through their distinct cultural perspectives.

\section{Cultural Context: Race, Class and the Press in Two American Nations}

Making sense of how news stories and ideological beliefs are framed requires explanation of basic cultural assumptions in the nations under study. The United States and Brazil are inversely similar. The northern part of the United States is very similar to the southern part of Brazil, in that both areas are largely industry-based and 
comprised of predominantly white populations. Similarly, the United States' south and Brazil's north are comparable, with both locations having histories of slavery and poverty, or, traditionally, being home to black minorities. Race, however, is more likely to be addressed than is class in the US media, but class is more likely to be discussed than race in Brazilian media (Straubhaar, 2007).

One reason for the media openness toward class in Brazilian media is the Brazilian notion of racial democracy, or equality among races. Forty years post slavery, in the 1930s, Brazilian sociologist Gilberto Freyre advanced this concept to unite a racially diversified population. It is considered by many critics to be a myth (Chaka, 2005; Sheriff, 2001; Stamm, 1997). Yet, racial democracy remains a critical component of Brazilian national identity (De Sousa \& Nascimento, 2008) and way of life (Htun, 2005). While racial democracy is more commonly associated with race, it also comprises moves for equality among genders and better socio-economic positioning.

Another interesting contrast between the two nations is the decline versus the explosion of newspaper industries. While newspapers flounder in the United States largely because of consistently decreasing advertising revenues (The Pew Research Center's Project for Excellence in Journalism, 2012), “...the people of Brazil are reading newspapers in bigger numbers than ever. In fact, print media is noisily booming in South America's biggest economy" (Clark, 2009). Brazil's Verifying Institute of Circulation (Instituto Verificador de Circulação) recently posted Brazilian newspaper circulations have been steadily increasing, setting a record in 2012 for daily circulation (Propmark, 2012).

Brazilian newspaper growth stems from increasing literacy rates among the Brazilian populace and a rise in the middle class (Duailibi \& Borsato, 2008, p. 83). The period of economic growth and stability unknown historically to Brazilians concurrent with US citizens' struggles through the worst economic downturn since the Great Depression has moved Brazil further onto the world stage as a power.

Economic conditions and improved literacy rates empower more Brazilians to seek out news and information from newspapers. Ironically, newspapers, at least in Brazil, remain an elitist medium. Further, although press censorship has eroded since the 1970s, particularly with Brazil's 1985 move to democracy, encouraging "media opening," the media system remains ranked as being partly-free (Freedom House, 2012). Media opening is the "process by which mass media become more representative of societal viewpoints and more independent of official control" (Porto 2007, citing Lawson, 2002, p. 381). One of the reasons for this designation could be the news media's failure to address race (Rosas-Moreno, 2010), although Freedom House rankings are based on legal, political and economic factors. Still, the Brazilian journalists' search for "truth" has maintained their credibility among Brazilians as intellectuals, ranking them second only to the Catholic Church (Moreira \& Helal, 2009; Candiani, 2009; Alves, 2003).

The Brazilian model of journalism has been greatly influenced by the American model (Alves, 2003; Herscovitz, 2004), to the extent that Brazil's Poder Moderador (Moderating Branch) is reminiscent of the US's 'Fourth Branch' rhetoric. Brazil's press form, however, is an adaptation, rather than an adoption, of the model (Albuquerque, 2005), signifying differences that enrich a comparison between how the US and Brazilian presses cover a shared news event. For instance, the Brazilian journalist's value system stems from at least a number of foreign influences on local journalistic patterns plus specific historical conditions such as the process of democratic consolidation (Herscovitz, 2004).

\section{Problem Statement}

In the case of this kidnapping, the battle over a boy between two men of two nations of the right race and class percolated the story into the media spotlight. The attention the story garnered via media escalated the situation to the highest levels of both lands, forcing a decision that ruled in favor of the boy being returned to his US father. How, then, did the national and local presses of two similar nations with dissimilar presses involved in an international child abduction case frame the shared news event, from its inception to its conclusion? What might that framing indicate about how ideologies influence journalistic practices?

\section{Media and Method}

The press under scrutiny include the US' New York Times and Brazil's Folha de São Paulo - both premiere national dailies. The Star-Ledger, a New Jersey-based local daily, and O Jornal do Brasil, a national and local Rio-based daily, represent the local print press. These local papers were chosen because New Jersey is David's home and The Star-Ledger is the state's largest newspaper. Similarly, Rio had been Bruna's and Sean's home, and Jornal (Note 1), produced daily out of Rio, is known for having set the standard for Brazilian journalism over many years. Forty-one relevant articles form the database of materials. This chart overviews the news articles included: 
Chart I. News Article Summary

\begin{tabular}{lccc}
\hline \multicolumn{1}{c}{ Nation } & Local Press & National Press & Total \\
\hline United States & 9 & 10 & 19 \\
Brazil & 7 & 15 & 22 \\
Total & 16 & 25 & $\mathbf{4 1}$ \\
\hline
\end{tabular}

Using the key terms "David Goldman" and "Sean," each medium's online archive was used to extract articles from the five-year abduction time period, ranging from June 2004 to about one month past its December 2009 resolution, January 25, 2010. Since only 10 articles surfaced from the NYT search, this figure was used as a general guideline to determine how many articles would be sampled from the remaining three media. The replicated procedure produced a total of 76 articles via Folha's archive, 72 articles via Jornal's site, and 289 (Note 2) results in the Star-Ledger. Blogs, comments, and/or other audience-generated content, were excluded, and only "news stories" or newspaper editorials were captured for evaluation. Random start points were used to systematically pull stories from the bodies of articles that surfaced from each medium to ensure a more objective analysis (Poindexter \& McCombs, 1999). Ultimately, 15 germane Folha, seven relevant Jornal and nine pertinent Star-Ledger articles surfaced for sample inclusion and analysis.

Through a qualitative textual analysis the stories were comparatively narratively analyzed (Berger, 1997, 2005) to understand news framing of the abduction. Comparative narrative analysis is thorough and permits a cross-cultural comparison of press clippings from nations with differing press systems to arrive at inductive, theoretical, crystallized interpretations. The qualitative process is reciprocal and dynamic, with news themes in each medium triggering consideration then evaluation of possible news themes in other texts. Researchers worked together to make connections to larger ideologies to give voice to some frames embedded within or alluded to among national and local media.

Following Van Gorp's (2010) news framing analysis guidance, for 'best results' only two coders - US, female, Caucasian researchers, one being fluent in Portuguese although not Brazilian — did "all the work" (p. 100). After initial agreement on coding protocols for several news stories, samples were independently evaluated (Van Gorp, 2010, p. 100), and the researchers independently read articles from the sample, one from the national US press and the other from the local US press, to see what frames emerged from the brief analysis. This initial-reading conferment served as a "member check" for trustworthiness. In the qualitative paradigm this allows researchers to begin the larger analysis with a similar ideological familiarity. This initial agreement was crucial, since one problem for the frame analyst is blindness to one's own cultural news norms, which can cause the most obvious news frames to be overlooked (Van Gorp, 2010, p. 88). As Blumler and Gurevitch (1995) have argued, comparing at least two cultures' news reports on similar topics serves to decrease unintended narrowness, increase awareness of systems, and help differences and similarities from news normalization and routinization percolate. Further, such cross-cultural and cross-dimensional, i.e., the national compared with the local, news report comparisons should dismiss 'per chance' findings and reveal cultural and societal similarities and differences in news story telling (Shoemaker \& Reese, 1996), enriching findings.

This interlaced, systematic inductive process with researchers, who served as the instruments of evaluation, was used to help give this project trustworthiness, or merged credibility, transferability, dependability and confirmability (Lincoln \& Guba, 1985, p. 219). In the absence of quantitative analysis and reliability checks, these measures serve to determine the soundness and rigor of qualitative research. To increase the credibility of the findings, the researchers systematically and objectively selected articles for inclusion; conferred on methods and emerging findings during data analysis; and relied on context to "frame findings" (Shenton, 2004). To increase transferability, dependability and confirmability, the researchers carefully mapped the research process and revealed background details to provide transparency in possible researcher bias (Shenton, 2004). "To ensure reliability in qualitative research, examination of trustworthiness is crucial... Reliability and validity are conceptualized as trustworthiness, rigor and quality" (Golafshani, 2003, pp. 601, 604). These strategies were deployed to achieve crystallization of results, or an idealized form of triangulation. "Crystallization, without losing structure, deconstructs the traditional idea of 'validity' [and]... provides us with a deepened, complex, thoroughly partial, understanding of the topic" (Richardson \& St. Pierre, 1994, p. 522). 


\section{Findings}

Cataloguing the sampled articles in preparation for analysis indicated a news coverage publication pattern; stories could be grouped into three distinct periods. The first could be called the "Refused Attempts" era, or a combination of times when David Goldman went to Brazil in the hopes of regaining custody of his son. Six of these 10 articles, or 60 percent, were published June 2009 across all papers. In this time frame, no story appeared earlier than The New York Times' Feb. 25, 2009 article. The second could be classified as the reunion articles, or the news stories detailing the final events leading up to David's regaining custody of Sean and the two leaving Brazil together for the United States as father and son. Twenty-seven of the 28 total articles in this section, or 96 percent, were published in December 2009 within about one week of the Goldmans' exeunting Brazil. The third division addresses the aftermath of Sean's return to his native USA. Only the US national and local press covered this, with all three articles occurring January 2010:

Chart II. News Article Publication Divisions

\begin{tabular}{lcccc}
\hline \multicolumn{1}{c}{ Daily } & Refused Attempts & Reunification & Repatriation & Total \\
\hline NYT & 2 & 6 & 2 & 10 \\
Folha & 2 & 13 & 0 & 15 \\
Star-Ledger & 4 & 4 & 1 & 9 \\
Jornal & 2 & 5 & 0 & 7 \\
\hline
\end{tabular}

Close readings and comparisons of US and Brazilian press reveal interesting similarities and differences in the news framing of this event. The similarities reveal one salient latent news frame that straddles both nations: $A$ game of high stakes. When considering what is absent from national and local news reports, the salient latent news frame The muted prize rises. Comparing how each nation framed the event, differences disclose two salient latent frames. US citizen superhero surfaces from national and local US reports, and Remember the press, forget the subject interlaces national and local Brazilian reports. None of these frames is dominant in any one article. Rather, they emerge through the composite understanding of how the media are telling the story of the shared news event.

\subsection{US and Brazilian Salient Latent News Frame: A game of high stakes}

Readings and comparisons of US and Brazilian presses situate this story not about one family or even family members at odds but about a relationship between two countries. Perhaps more interestingly, this custody case seems paramount in terms of international relations between the United States and Brazil. One NYT article, for example, detailed how the "high-profile international abduction and custody case" had "reached the highest levels of the Obama administration" (Feb. 25, 2009). In fact, "The case has become a sore point in the relationship between the United States and Brazil" (NYT, Feb. 25, 2009, italics added).

The words "sore point in the relationship" are interesting in the context of the many US and Brazilian articles that name this story as an important point of contention between the two countries. It seems that Sean's kidnapping is one that threatens diplomatic relations. The Brazilian press echoed this, pinning pressure on young Sean. It labeled him "pivotal to" (Folha, Dec. 24, 2009) and "the target of a diplomatic dispute between Brazil and the United States" (Folha, Dec. 30, 2009, and Dec. 16, 2009, italics added).

Additional articles stating basically the same notion help solidify this framing. An article published nearly one year later in the New York Times, on Dec. 24, 2009, noted the magnitude of the case in terms of international relations. The newspaper lead said that Sean boarded a plane with his American father "ending a five-year battle in the court systems of Brazil and the United States that threatened to upset diplomatic relations between the countries" (NYT, Dec. 24, 2009, italics added). Similarly and around the same time, another US story explained, "The case, which has become a source of tension between the United States and Brazil and has reached the highest levels of both governments, began in June 2004" (NYT, Dec. 22, 2009, italics added).

The Brazilian press, at both the national and local levels, not only situates this story as a conflict between two nations, but elucidates the degrees to which Brazil can be affected by not complying with Sean's return to the US. Folha reported, "To defend the surrender of Sean to the father, the AGU [Advocacia-Geral da União, or 
Solicitor-General's office] remembers that the case could result in the placing of sanctions on the nation" (June 8, 2009, italics added).

Taking matters a step further, Folha explained that the Brazilian justice system

...is trading the child in order to close an economic contract. In the last week, an American senator presented a motion suspending voting of a program of tariff exemption that would benefit Brazilian exports. After the STF [Supremo Tribunal Federal, or the Brazilian Supreme Court]'s decision to permit the return of the boy to the father, the program was approved. (Dec. 25, 2009)

The US local press also contextualized the story in terms of international ramifications, but as a type of turning point in child abduction cases:

More important, if the court rules in Goldman's favor, it will set a precedent of honoring international agreements that should ripple through South America. More than 2,000 children are kidnapped overseas every year. (Star Ledger, Feb. 20, 2009)

Star-Ledger, the local US daily, also framed the story as one that deeply divided two countries. An Associate Press story offered: "President Barack Obama, the US Congress and Secretary of State Hillary Rodham Clinton have all urged the child's return" (Star-Ledger, Feb. 20, 2009). Opinion pieces published Feb. 20, 2009, and June 20, 2009, offered details about political figures' involvement in the case, thereby cementing it more so as a conflict between two nations rather than a family matter:

For Goldman, things may be looking up. Sens. Frank Lautenberf and Robert Menendez have urged Brazilian authorities to comply with international law.... Rep. Rush Holt has asked Secretary of State Hillary Clinton to intervene, and Rep. Chris Smith traveled to Brazil to help set up the tearful reunion of father and son. (Star-Ledger, Feb. 20, 2009)

Similarly, the local Brazilian press featured stories about two nations' international strain pivoting on one young man, given that both lands' leaders would be discussing Sean Goldman:

The president of the United States, Barack Obama, will converse about the custody of the North American boy Sean Goldman during the meeting that will take place this Saturday with president Luiz Inácio Lula da Silva, in the White House. (Jornal, March 13, 2009)

Although Brazil's local press seemed to recognize "the question should not be faced as "a diplomatic topic" between Brazil and the United States" (Jornal, March 13, 2009, italics added), it seemed cognizant that this was in fact how the story was being told. This notion of press self critique or commentary will be elaborated on in the salient news frame finding rising specifically from Brazilian press reports.

\subsection{US and Brazilian Salient Latent News Frame: The muted prize}

When considering the framing of the shared news event across both nations' media, it became obvious from what is not reported that a key consideration is left unanswered. The boy Sean seemed to be a muted prize, one with no say or voice in his own custody case.

US and Brazilian press peppered references to others speaking on his behalf through national and local accounts. But Sean was never quoted in any media story. This may be because he is a minor, only having turned 10 years of age May 25, 2010, which follows the time when he was in the media spotlight. In addition, when others spoke for him, comments primarily addressed that he should be allowed to express what he would like. If Sean received any voice, it was that of something to come, but something that never did. For example, "...the maternal grandmother of the child, Silvana Bianchi, solicits that the justice system hears the statement of the boy before he leaves Brazil" (Folha, Dec. 17, 2009). Similarly in a separate article, "...the boy should be heard by the justice system before he leaves the country" (Folha, Dec. 17, 2009). US reports echoed this sentiment:

Silvana Bianchi, Sean's maternal grandmother, told the privately run Agencia Estado news service... "His testimony has never been heard," she said. "As a Brazilian citizen, he deserves it. He is a child of nearly 10 and he knows quite well what he wants." (Star-Ledger, Dec. 17, 2009)

And, in the New York Times:

A lawyer for Ms. Bianchi's family said they... asked the Supreme Court of Brazil to let the boy make his wishes known in court... The court initially denied the request, but it has not issued a final ruling and will not reconvene until February. (Dec. 29, 2009)

However, one sole local Brazilian report, again commenting on a US report of David Goldman, did reference a voice for Sean through a type of double negative: 
...Sean Goldman never said he didn't want to be with the father - he never said "I don't want to go with you" or "I don't want to be with you." He never resisted. (Jornal, Dec. 28, 2009, italics added)

Meanwhile, one other national Brazilian report stated that

Sean would say [to Lins e Silva] he didn't want to stay with the [North American] dad, that in the last days [in Brazil] he only would cry and that the boy began to vomit at the American Consulate in Rio when he was delivered by the family for the exchange. (Folha, Dec. 27, 2009, italics added)

In sum, Sean is latently framed in both US and Brazilian reports as a child who is The muted prize. This frame is salient in both nations' news media.

\subsection{US Salient Latent News Frame: US citizen superhero}

US citizen superhero is a salient latent news frame that arose in national and local US press reports within the New York Times and Star-Ledger. It included several manifestations, such as good versus evil, the US pitted against Brazil, and either law-abiding or law-breaking. It coincided with the superhero motif prevalent in at least US culture, where superheroes are understood to combat villains and/or criminal actions, fighting to influence social and political issues to a greater good. This played out primarily in terms of national players; the United States citizens and lawmakers represented good by trying to follow the law, and Brazilian citizens and the court system were evil for both breaking and ignoring international law. This framing of the story occurred in the manner in which David and his ex-wife were portrayed and constructed in the US newspapers, how the families in the United States and Brazil were portrayed in the press, and in the way the legal and court systems were written about in both countries.

For example, the US press framed David as the victim of an evil woman's plot, while simultaneously explaining the she died in childbirth in 2008. Pointing to this dominant framing does not indicate he was not a victim; what is important is how the facts were presented, which lead to a very sympathetic perspective of Goldman's circumstances. Some give more details while others give less. Goldman is described as a man who "hadn't a clue" his wife planned to divorce him upon arriving in Brazil (NYT, Feb. 25, 2009), "at times choking back tears" (NYT, Dec. 29, 2009), and "sounding weary" (NYT, Feb. 25, 2009). Another quote read, "I am always getting kicked in the teeth and sent home" (NYT, Feb. 25, 2009). Sean Goldman's mother Bruna is portrayed in a matter-of-fact tone in both US newspapers with only a few repetitive statements. For instance, "The legal battle, waged in American and Brazilian courts, began when Sean's mother, a Brazilian, traveled with him from the United States to Brazil in 2004. She then asked for a divorce from Mr. Goldman and declared her intention to keep their son" (NYT, Dec. 23, 2009). Pained presentations seen in descriptions of Goldman, however, never appear in conjunction with the Brazilian family, who no doubt are feeling weary and tearful given that Sean is part of their family, too.

The family in Brazil is also demonized for publicly handing Sean over to his father rather than doing it in private. For example, in the New York Times an article explained, "Sean's Brazilian relatives, who had fought against returning him to Mr. Goldman, had refused various offers by the consulate to provide a calmer, more private way of transferring him inside the consular compound" (NYT, Dec. 24, 2009). Goldman's lawyer is then quoted saying that the Brazilian family just wanted dramatic photos of the event. An editorial in the Star-Ledger also illustrated this framing:

The step-father's family tried an appalling public relations maneuver this week, releasing a videotaped session with a psychologist in which Sean, surrounded by adults, says he'd be better off living in Brazil. The appeals court should give it no more weight than any other hostage's taped remarks. (June 20, 2009, italics added)

The US press framed Brazilian courts as lawbreakers through their failure to comply with the Hague Abduction Convention. While multiple court rulings evidence the situation may not be so clear cut in the Brazilian court system, the American newspapers' perspective presented this simply as a corrupt court system. For example, "The United States has complained about Brazil's handling of the case under The Hague Abduction Convention..." (NYT, Dec. 22, 2009). The implicit meaning here is that the United States was the rule enforcer, or The citizen superhero.

\subsection{Brazil Salient Latent News Frame: Remember the press, forget the subject}

Closely reading national and local Brazilian press articles revealed a salient latent news frame regarding how the Brazilian press handled covering the situation surrounding Sean Goldman. Press reporting on the media coverage seemed to trump what was actually happening to Sean. Would the American win custody of him, or would Sean 
stay with his Brazilian family, who "...had participated in more than 60 percent of his life" (Folha, Dec. 27, 2009)? The answer to this question seemed secondary, if even an issue.

As one Folha article pointed out, "The story was a special theme in the programs Larry King Live and NBC Today Show, where the secretary of State, Hillary Clinton, defended that the boy's guardianship should be the father's" (Dec. 16, 2009, italics added). Similarly, Jornal highlighted,

The possibility of the presidents discussing the question had been anticipated today through the newspaper Washington Post, which gave the story front-page attention. The theme that would be most discussed between the two nations won't be energy, the environment or security, but the guardianship of a little eight-year-old boy, affirmed the publication (March 13, 2009, italics added).

The Brazilian press seemed caught up in its own analysis of what medium said what, rather than what was actually happening with story characters.

Perhaps more importantly, the Brazilian press stressed its own poor handling of and intervention in Sean's transition from his Brazilian family to his American father. According to Jornal, on Christmas Eve, "there was a ruckus with the press when the stepfather arrived with Sean at the American Consulate in Rio de Janeiro" (Dec. $28,2009)$. Further, Goldman was reported as saying "'I can't believe that anyone with common sense and love could create the spectacle that they created...' to an American television station" (Dec. 28, 2009, italics added). Perhaps more poignantly,

...the family's impression was the worst possible... The Brazilian family arrived with the boy one hour later and had problems entering the diplomatic headquarters due to the huge number of journalists... who had conglomerated in the entrance. (Jornal, Dec. 24, 2009, italics added)

Brazilian press reports repeatedly featured how Sean's handing over from his Brazilian family to his American father was neither personal nor private, but very public and was interfered with and interrupted by the media. In so doing, they removed the spotlight from subject, Sean, to themselves, giving themselves a role in the story. In a sense, this "breaks the third wall" of any production, interrupting and influencing how the story should transpire.

The following chart summarizes findings to this point:

Chart III. Salient Latent News Frames Associated with Sean Goldman's Kidnapping

\begin{tabular}{|c|c|c|c|}
\hline Frame & Meaning & US Press & $\begin{array}{l}\text { Brazilian } \\
\text { Press }\end{array}$ \\
\hline A game of high stakes & One young man is the symbol of two nations' rivalry & Present & Present \\
\hline The muted prize & $\begin{array}{l}\text { Sean is never given a voice in the news story of his own } \\
\text { kidnapping }\end{array}$ & Present & Present \\
\hline US citizen superhero & $\begin{array}{l}\text { The US and David Goldman are the good guy because } \\
\text { they are the ones fighting to uphold the law }\end{array}$ & Present & Not present \\
\hline $\begin{array}{l}\text { Remember the press, } \\
\text { forget the subject }\end{array}$ & $\begin{array}{l}\text { Press self-critique rather than story character dominates } \\
\text { coverage }\end{array}$ & $\begin{array}{l}\text { Not } \\
\text { present }\end{array}$ & Present \\
\hline
\end{tabular}

\section{Discussion}

The qualitative framing analysis of this international child custody debate in 41 US and Brazilian national and local press articles resulted in a pattern of news publication periods. In this first wave of sampled article analysis, three snapshots emerge from the captured coverage ranging from June 2004, when Sean was abducted, to January 2010, shortly after his return to the USA. They occur prior to the media frenzy of the father-son reunion, or the "Refused Attempts" era, which includes 10 of the 41 articles, or 24 percent of the sample; during the reunion, or the "Reunification" period, which contains 29 of the 41 articles, or 71 percent of the sample, and following it, or the "Repatriation" time, which was only covered by the US press and comprises three of the 41 articles, or roughly 7 percent ${ }^{1}$.

${ }^{1}$ Rounding calculations equates to slightly more than 100 percent. 
Following, the constant comparative technique gave rise to four salient latent news frames. Two of those frames, A game of high stakes and The muted prize, are present in both the US and Brazilian presses. However, the US citizen superhero frame is unique to the US press, while the Remember the press, forget the subject frame occurs only in the Brazilian press. The Shoemaker and Reese hierarchical model of news influences (1996) helps makes sense of these findings, providing insight into how ideological concepts influence US and Brazilian journalistic practices and/or institutions.

The dominant framing in both nations' press reports $-A$ game of high stakes - set the story up to hold great importance, although it received relatively little coverage in the New York Times during a one-year period. The significance placed on the particular case of Sean Goldman is interesting in the context of a quote toward the end of a key New York Times article: "There are currently about 50 unresolved Hague Convention cases involving children who were abducted from the United States and are being kept in Brazil, the State Department said" (NYT, Feb. 25, 2009). An obvious question becomes, why does this case hold such significance? After all, the media covered the story before its resolution, which could increase its newsworthiness. At the ideological level of Shoemaker and Reese's (1996) hierarchical model of news influences, notions of race and class as they pertain to this case along with the dramatic details suggest explanation.

Liebler (2004) argued that white, middle and upper-middle class families who are the victims of crimes are able to get their stories into the paper and public consciousness because they have the education and means to access the media, political figures, and law enforcement. In the case of David Goldman, a white male of at least middle-class status, he had the support of a representative from New Jersey who helped him fight for his son and introduced legislation to place a time limit on these types of court battles (NYT, Dec. 29, 2009). At least at the ideological level in US news, Goldman's story fit enough newsworthy criteria to be told.

Similarly, stepfather Lins e Silva's portrayal in the news media demonstrated him to be at least a member of the middle-class and, accordingly, more likely to have his situation covered. Lins e Silva was consistently constructed according to his class at least in US reports; he was often being described as "a well-connected lawyer from a prominent family" (NYT, Dec. 24, 2009) who "...continued the fight to keep the boy in Brazil" (NYT, Dec. 22, 2009).

Perhaps more important is the influence the (white) dads' socio-economic position had on the (inter)national story's outcome. Goldman demonstrated media expertise in his ability to bring this battle to (inter)national attention. He was able to enlist powerful players, including a US senator, US Secretary of State, and US President Barack Obama. At the same time, Brazilian stepdad and international family lawyer João Paulo Lins e Silva was able to stalemate Sean's return to the United States for years, even after his mother's passing. While it should be noted that Brazilian law favors maternal custody rights, it is still necessary to highlight the success Lins e Silva experienced in keeping Sean in Brazil. This is indicative of what two men of the right class and race can do at least within their own nations to accomplish their goals.

Further, Goldman's and Lins e Silva's "achievements" - getting Sean back and holding onto Sean — relate with what Heider (2000) found to be the case in his race and class news study. In brief, predominantly white, at least middle class newsrooms - like those found in both the US and Brazil — favor stories that resonate with reporters' race and class. This might suggest other levels of influence in play. In other words, a reporter's individual characteristics influence the content, suggesting influence at the individual, organization and media routines levels, according to the hierarchy of influences model (Shoemaker and Reese, 1996). Both Goldman and Lins e Silva also demonstrate their education or social capital. Had Sean or Goldman or Lins e Silva been Afro-American/Afro-Brazilian, respectively, or less educated or media savvy, research indicates that the likelihood of this story being told at all is slim. Again, this is indicative of what two men of the privileged class and race can do at least within their own nations to accomplish their goals, and it perhaps gives insight into part of the reason why the at least 50 children abducted to Brazil remain unreturned, let alone unreported.

It is important to note differences in how race and class are addressed in the US and Brazilian presses as this speaks to an ideological level of influence on media content. As aforementioned, race is more likely to be spoken of in US media, while class is more likely to be addressed in Brazilian. With regard to Sean's abduction, his race is never specifically addressed, even in US media. But it doesn't need to be; all photos show Sean to be white, in all nations' media. This is the same for the father and stepfather involved. The silent acknowledgement of Sean's whiteness, along with that of his father and stepfather, further evidence how race continues to be an important (unspoken) element of news story selection at least within the US and Brazilian press systems. It is impossible to know if the opposite - a nonwhite, less well-off abductee and/or his/her parent(s) receiving notable media attention - occurs. But, research indicates it is less likely. 
Taking into account the different levels of press freedom, and considering this at the ideological level of news influences, it is interesting to note that although redundancy also occurred with the Brazilian press, it did offer more information regarding the case than the US press. In fact, the Brazilian press seemed more tabloid-esque, or novela-esque, in its telling, more so in style than in fact presentation. For example, Jornal wrote about how the Brazilian justice system recognized Bruna's divorce request without Goldman's consent. "Before American laws, they remained married. Free from her commitment to Goldman, Bruna married again, this time to the lawyer João Paulo Lins e Silva, but during the birth of her second child, she died, in 2008" (Jornal, Dec. 28, 2009). Further, the Brazilian press gave more detail to certain scenes, stylistically differentiating it from US reports. From Folha:

David was greeted by an American Consulate representative and left the airport escorted by special airport security as well as military police. He went from there to a hotel in Copacabana. (Dec. 17, 2009)

The frame US citizen superhero, offering a story of opposites as in US versus Brazil and good versus evil, illustrated a level of conflict that while newsworthy proved too simplistic and misleading. In constructing the stories in this manner the US newspapers presented a story that ideologically resonates in a (popular) culture asphyxiated with the superhero motif. But, stories showed narrow understanding of international kidnapping cases and left much of the complexity of the issue out. Journalists made the stories much broader than just one family's struggle, but at the same time the family came to inaccurately represent the larger issue of international abductions. This type of reporting strategy — dichotomous reporting — serves neither an audience nor community well. It also further evidences (scholarly) critique of the (US) news media's inability to explain complex issues.

The Brazilian news frame, Remember the press, forget the subject, may be the Brazilian press' expressed sensitivity to its partly-free ranking, or its attempt to make its actions known, although it continues to experience "media opening." For instance, as the Brazilian government continues to mature since its 1985 move from dictatorship to democracy, its transitional press remains more preoccupied with instrumental rather than idealistic practices. Its focus has been "meeting standards of accuracy, beating deadlines, juggling sources, and scooping competitors rank more prominently than bringing political reform or democratic accountability" (Waisbord, 2000, p. 187). It might also reflect what the media published toward the end of the story, as the case reached resolution, rather than as it developed, when the Brazilian press seemed to take Sean's Brazilian family's side. However, given the prominence that telenovelas have in Brazilian society, it makes sense how the Brazilian news storytelling might provide more personal details than the US press. This should not be underestimated. Telenovelas are not only alternative news sources in Brazil, but the forums in which social issues are discussed (Rosas-Moreno, 2010). They are also "the Brazilian cultural product with the greatest audience, the most societal influence, the most sophistication in open television production" exporting Brazilian culture to more than 140 countries (University of São Paulo, Brazil, Agency News, 2004). The facts surrounding Sean Goldman's life resonate with Brazilian popular culture. Hence, the ideological level of the hierarchical model of news influences is satisfied in the Brazilian case.

Whether being featured by a free press or partly-free press, The muted prize, Sean, had no voice in the media portrayal of his own kidnapping. He was voiceless (Moeller, 2002) in perhaps the most significant time of his life, whether he would remain with his Brazilian family or return to the United States. Sean only went public with his side of the story two years following his return home. It seems clear that the target of a diplomatic dispute between two nations was symbolically used to politically charge negotiations between two American powers. Yet, both media systems, again regardless of their degrees of press freedom, left silent the voice of the story's main character as it told and perhaps shaped a potential precedent affecting (inter)national family law. As framing research has shown, the exclusion of material in a news story can be just as provocative as the inclusion (Cantrell \& Bachmann, 2008).

\section{Conclusion}

Journalists, influenced by their individual characteristics, organizations norms and routines, outside pressures and ideological constraints, are powerful social actors with the privileged opportunity to influence how audiences socially and politically interpret events and facts. As such, their work demands attention (Carragee \& Roefs, 2004), particularly when they operate in media systems experiencing different levels of press freedom yet covering a shared news event. This study attends to journalist's work, paying particular attention to how ideologies based on race and class might influence news.

This framing analysis considers US and Brazilian news coverage of the to-date one successful child returned from Brazil to the United States, from the story's inception to its conclusion. Tracing the coverage of the stories 
indicates three periods of attention, with the media frenzy surrounding the chief event: Sean's (possible) US homecoming. The comparative research of media discourses reveals the power of words and framing in constructing public images of social actors. (Note 3) International law is very clear: "Under Federal and State laws, international parental child abduction is a crime. In fact, the 'Protect Act' of 2003 makes attempted international parental child abduction a crime" (US Government, 2010).

Many international child abductions occur yearly. So, why was this abduction and custody story covered, and it framed the way it was? The facts reveal this as an unusual story, one that might garner some media attention. They also revealed how both players, at least at some point, used the media as a tool in negotiations; David wrote a letter to his local media, and David indicated the media were also accessed in Brazil. That the players involved in the story come from the right race and class evidences how and why this one incident became a shared news event and how it could rise to the highest offices of each land.

Analysis has shown that some cultural differences, within the context of varying media systems, can account for differences in how a story was told. Generally speaking, the US press tells a dichotomous tale of good versus evil and/or law abiding versus law breaking nations and people — an ideologically pro-American stance, and the Brazilian press focuses on media's own telling of the story, rather than the story itself - a twist on the cultural-engulfing telenovela. Both nations, with comparable race and class histories, tell a similar story of a young man's situation affecting two American powers' diplomatic relations, which, over the course of time, have tottered between being more friendly or foe-ish. Again, that focus is not on the family, but rather powerful players who aim to win the boy. On a practical level, this study illustrates the influence dominant ideological understandings of race and class have on media content. From a theoretical standpoint, the research adds credibility to the hierarchy of influences model, particularly that of the ideological level, but also begs for further research. More comparative studies about (inter)national journalistic practices and institutions could help solidify these findings and interviews and observation within newsrooms can more clearly articulate the ways the various levels of influence intermingle in the production of news.

While careful measures have been taken to ensure crystallization of results, further investigation into (lack of) media coverage of other international child abduction cases is needed to solidify these findings. For instance, are these findings indicative of larger trends or simply a product of the unique nature of this case? (Note 4) Further, news media's ability to affect social justice at the (inter)national level(s) stands in need of critique and evaluation, since governments are enacting rules that govern the composition of the family.

\section{References}

Albuquerque, A. D. (2005). Another "Fourth Branch": Press and political culture in Brazil. Journalism, 6(4), 486-504. http://dx.doi.org/10.1177/1464884905056817

Alves, R. C. (2003). Status of media in Brazil. In D. H. Johnston (Ed.), Encyclopedia of international media and communications (Vol. 1, pp. 129-138). San Diego, CA: Academic Press.

Berger, A. A. (1997). Narratives in popular culture, media, and everyday life. Thousand Oaks, CA: Sage.

Berger, A. A. (2005). Media analysis techniques (3rd ed.). Thousand Oaks, CA: Sage.

Blumler, J. G., \& Gurevitch, M. (1995). The crisis of public communication. London: Routledge. http://dx.doi.org/10.4324/9780203181775

Bring Sean Home Foundation. (2012a). David's story. Retrieved April 24, 2013, from http://bringseanhome.org/goldman-case/davids-story/.

Bring Sean Home Foundation. (2012b). Holt statement on discussion with Secretary of State Clinton about Sean Goldman Case. Retrieved April 24, 2013, from http://bringseanhome.org/goldman-case/u-s-government-action/holt-statement-on-discussion-with-secretary -of-state-clinton/

Candiani, H. R. (2009). Journalists and intellectuals in the origins of the Brazilian press (1808-22). Journalism, 10(1), 29-44. http://dx.doi.org/10.1177/1464884908098319

Cantrell, T. H., \& Bachmann, I. (2008). Who is the lady in the window? A comparison of international and national press coverage of First Female Government Heads. Journalism Studies, 9(3), 429-446. http://dx.doi.org/10.1080/14616700801999253

Carragee, K. M., \& Roefs, W. (2004). The neglect of power in recent framing research. Journal of Communication, 54(2), 214-33. http://dx.doi.org/10.1111/j.1460-2466.2004.tb02625.x 
Casares, C. (2009, March 15). Obama brings up awkward David Goldman case to Brazil President Lula da Silva. $\begin{array}{lllll}\text { Guanabee } & \text { Retrieved } & \text { April } & \text { 2013, }\end{array}$ http://guanabee.com/2009/03/obama-david-goldman-case-to-brazil-president-lula-da-silva/.

Chaka, M. R. (2005). The land of miscegenation: Is the racial democracy theory in Brazil a myth? (Unpublished doctoral dissertation). Morgan State University, Baltimore, MD.

Clark, A. (2009, October 12). Brazilian newspapers celebrate a rise in circulation: Print media booms in South America's biggest economy. The Guardian. Retrieved from http://www.guardian.co.uk/media/2009/oct/12/brazil-newspapers-circulation.

Connor, T. (2012, April 26). N.J. custody tug-of-war kid Sean Goldman: No more 'mixed feelings' about reunion with dad. New York Daily News. Retrieved April 24, 2013, from http://www.nydailynews.com/news/national/n-custody-tug-of-war-kid-sean-goldman-mixed-feelings-reunio n-dad-article-1.1067937.

Contreras, J. (2000). Covering Elian in print: How did the Miami media do? The Harvard International Journal of Press/Politics, 5(4), 123-127. http://dx.doi.org/10.1177/1081180X00005004010

D'Angelo, P. (2010). Conclusion: Arriving at the horizons of news framing analysis. In P. D'Angelo P, \& J. A. Kuypers (Eds.), Doing news framing analysis: Empirical and theoretical perspectives (pp. 356-367). New York, NY: Routledge.

De Sousa, L. C., \& Nascimento, P. (2008). Brazilian national identity at a crossroads: The myth of racial democracy and the development of black identity. International Journal of Politics, Culture, and Society, 19(3-4), 129-43. http://dx.doi.org/10.1007/s10767-008-9023-y

Duailibi, J., \& Borsato, C. (2008, April 2). Ela Empurra o Rescimento [It pulls the rebirth]. Veja, pp. 82-89.

Entman, R. M. (1993). Framing: Toward clarification of a fractured paradigm. Journal of Communication, 43(4), 51-8. http://dx.doi.org/10.1111/j.1460-2466.1993.tb01304.x

Esser, F., \& D'Angelo, P. (2006). Framing the press and the publicity process in German, British, and US general elections: A comparative study of metacoverage. Harvard International Journal of Press/Politics, 11(3), 44-66. http://dx.doi.org/10.1177/1081180X06289188

Finkelhor, D. (2002/2003). What the numbers tell us. The Front Line. Alexandria, Virginia: National Center for Missing \& Exploited Children.

Freedom House. (2012). Freedom of the press. Retrieved from http://www.freedomhouse.org/report-types/freedom-press.

Gamson, W. A., \& Modigliani, A. (1989). Media discourse and public opinion on nuclear power: A constructionist approach. American Journal of Sociology, 95(1), 1-37. http://dx.doi.org/10.1086/229213

Golafshani, N. (2003). Understanding reliability and validity in qualitative research. The Qualitative Report, 8(4), 597-607.

Guzmán, I. M. (2005). Gendering Latinidad through the Elián news discourse about Cuban women. Latino Studies, 3, 179-204. http://dx.doi.org/10.1057/palgrave.1st.8600141

Heider, D. (2000). White news: Why local news programs don't cover people of color. Mahwah, NJ: Lawrence Erlbaum Associates.

Herscovitz, H. G. (2004). Brazilian journalists' perceptions of media roles, ethics and foreign influences on Brazilian journalism. Journalism Studies, 5(1), 71-86. http://dx.doi.org/10.1080/1461670032000174756

Htun, M. (2005). Racial quotas for a 'racial democracy.' NACLA Report on the Americas, 38(4), 20-5.

Lewis, S. C., \& Reese, S. D. (2009). What is the War on Terror? Framing through the eyes of journalists. $\begin{array}{lllll}\text { Journalism \& Mass Communication } & \text { Quarterly, }\end{array}$ http://dx.doi.org/10.1177/107769900908600106

Liebler, C. M. (2004). Tales told in two cities: When missing girls are(n’t) news. In D. Heider (Ed.), Class and news (pp. 199-212). Lanham, MD: Rowman \& Littlefield.

Lincoln, Y. S., \& Guba, E. G. (1985). Naturalistic inquiry. Newbury Park, CA: Sage.

Méndez-Méndez, S., \& Alverio, D. (2001). Network brownout 2001: The portrayal of Latinos in network television news, 2000. National Association of Hispanic Journalists. 
Moeller, S. D. (2002). A hierarchy of innocence: The media's use of children in the telling of international news. The Harvard International Journal of Press/Politics, 7(1), 36-56.

Moreira, S. V., \& Helal, C. L. R. (2009). Notes on media, journalism education and news organizations in Brazil. Journalism, 10(1), 91-107. http://dx.doi.org/10.1177/1464884908098322

Poindexter, P. M., \& McCombs, M. E. (1999). Research in Mass Communication: A Practical Guide. New York, NY: Bedford/St. Martin's.

Porto, M. P. (2007, May). Trends in Brazilian election news coverage. Paper presented at the 57th Annual Conference of the International Communication Association (ICA), San Francisco, California.

Propmark. (2012). "Jornais atingem maior média histórica no primeiro semestre de 2012. [Newspapers attain the largest historical media in the first semester of 2012]." Retrieved from http://propmark.uol.com.br/midia/41167:jornais-atingem-maior-media-historica-no-primeiro-semestre-de-2 012.

Reese, S. D. (2003). Framing public life: A bridging model for media research. In S. D. Reese, O. H. Gandy, \& A. E. Grant (Eds.), Framing public life: Perspectives on media and our understanding of the social world (pp. 7-32). Mahwah, NJ: Erlbaum.

Richardson, L., \& St. Pierre, E. A. (1994). Writing: A method of inquiry. In N. K. Denzin, \& Y. S. Lincoln (Eds.), Handbook of qualitative research (pp. 473-500). Thousand Oaks, CA: Sage.

Rosas-Moreno, T. C. (2010). Media representations of race cue the state of media opening in Brazil. International Journal of Communication, 4. Retrieved April 25, 2013, from ijoc.org/ojs/index.php/ijoc/article/viewFile/751/408.

Semple, K. (2009, February 24). Court battle over a child strains ties in 2 nations. The New York Times. Retrieved from http://www.nytimes.com/2009/02/25/nyregion/25custody.html.

Shenton, A. K. (2004). Strategies for ensuring trustworthiness in qualitative research projects. Education for Information, 22, 63-75.

Sherrif, R. E. (2001). Dreaming equality: Color, race, and racism in Urban Brazil. New Brunswick, NJ: Rutgers University Press.

Shoemaker, P. J., \& Reese, S. D. (1996). Mediating the message: Theories of influences on mass media content (2nd ed.). New York: Longman.

Stamm, R. (1997). Tropical multiculturalism: A comparative history of race in Brazilian cinema \& culture. Durham, NC: Duke University Press.

Stomp, S. (2012, April 27). David Goldman: Brazilians dragged my son through streets. Today Show. Retrieved April 24, 2013, from http://www.today.com/id/47204848/ns/today-today_news/t/david-goldman-brazilians-dragged-my-son-thro ugh-streets/\#.UXhCzoVZzKQ.

Straubhaar, J. D. (2007). World television: From global to local. Thousand Oaks, CA: Sage.

The Pew Research Center's Project for Excellence in Journalism. (2012). The State of the News Media 2012: An Annual Report on American Journalism. Retrieved from http://stateofthemedia.org/2012/newspapers-building-digital-revenues-proves-painfully-slow/newspapers-b $\mathrm{y}$-the-numbers/.

Tuchman, G. (1978). Making news: A study in the construction of reality. New York: Free Press.

University of São Paulo, Brazil, Agency News. (2004, January 27). Teledramaturgia ganha caráter científico com trabalho do Núcleo de Telenovelas [Teledrama gains scientific character with the work of the Center for Telenovelas]. Retrieved from http://www.usp.br/agenciausp/repgs/2004/pags/007.htm.

US Government. (2010). International parental child abduction isn't 'just a custody issue.' It's a crime. US Passport Pamphlet. USA.

Van Gorp, B. (2007). The constructionist approach to framing: Bringing culture back in. Journal of Communication, 57(1), 60-78.

Van Gorp, B. (2010). Strategies to take subjectivity out of framing analysis. In P.D’Angelo, \& J. A. Kuypers (Eds.), Doing news framing analysis: Empirical and theoretical perspectives (pp. 84-109). New York, NY: Routledge. 
Waisbord, S. (2000). Watchdog journalism in South America: News, accountability and democracy. New York: Columbia University Press.

\section{Notes}

Note 1. At the time of this study, O Jornal do Brasil still appeared in paper format. However, in August 2011, it was Brazil's first newspaper to move to an online-only format. It is considered a zombie newspaper by many, but in the past it survived government censorship and led the way in many aspects of journalism, including being Brazil's first newspaper to offer news online.

Note 2. The large difference - 289 compared with 72 - in quantity of items surfacing through each medium's online search engines includes variance in the types of material that percolate, given the differing types of search engines and options available. For instance, in the case of the Star-Ledger, every comment at the end of any article that mentioned David Goldman or Sean popped up in the initial 289 results. This gravely skewed the actual amount of news coverage given to the shared news event, mandating heavy data cleaning.

Note 3. We owe this insight to a kind reviewer.

Note 4. We owe this insight to another kind reviewer.

\section{(cc) EY}

This work is licensed under a Creative Commons Attribution 3.0 License. 